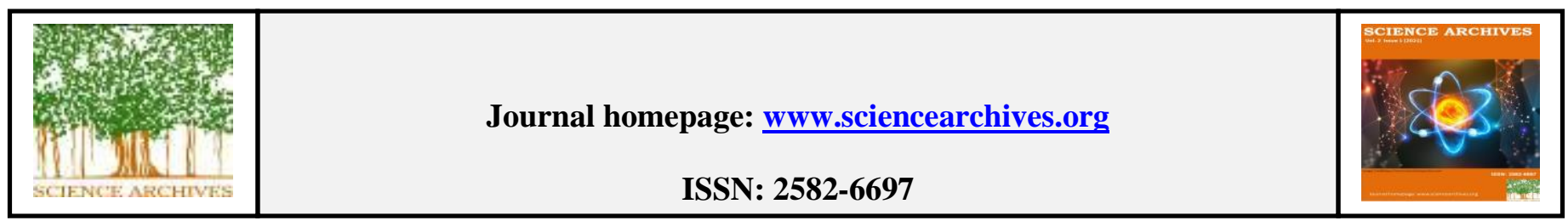

Original Research Article

http://dx.doi.org/10.47587/SA.2021.2101

\title{
Response of pea to boron, amino acids, and silicon spray
}

\author{
Ali H. Jasim and Mohsen H. Mohsen \\ Agriculture College, Al-Qasim Green University, Iraq \\ *Corresponding author: ajasim11@ gmail.com \\ Received: Nov 23, 2020 / Revised: Feb 19, 2021/ Accepted: Mar 9, 2021
}

\begin{abstract}
A field experiment was conducted in Al-Souera, $50 \mathrm{~km}$ south of Bagdad in the winter season 2019/2020 to study two levels of boron spray (control and $2 \mathrm{mg} \mathrm{L-1}$ ), three levels of amino acids (control, 1.5 and $3 \mathrm{mg} \mathrm{L-1}$ ), and four levels of Silicon as potassium silicate (control, 1, 2 and $3 \mathrm{mg} \mathrm{L-1).} \mathrm{A} \mathrm{randomized} \mathrm{complete} \mathrm{block} \mathrm{design} \mathrm{with} \mathrm{three} \mathrm{replications} \mathrm{was} \mathrm{used.} \mathrm{The}$ spraying process was done in two periods (45 and 90 days after planting). Pea seeds were planted in hills $30 \mathrm{~cm}$ apart on ridges $80 \mathrm{~cm}$ apart. The results showed that boron spraying caused significant increases in plant length $(112.27 \mathrm{~cm})$, leaf area $(101.2$ $\mathrm{cm} 2$ ), branches number per plant (8.4), leaves number per plant (88.41), chlorophyll index (43.91 SPAD), and plant dry seed yield $(57.7 \mathrm{~g})$. Amino acids spray treatments gave a significant effect and the level of $3 \mathrm{mg}$ L-1 was superior in plant length $(110.02 \mathrm{~cm})$, leaf area $(100.9 \mathrm{~cm} 2)$, branches number per plant (9.0), leaves number per plant (89.20), chlorophyll index (44.09 SPAD), and plant dry seed yield $(57.9 \mathrm{~g})$. The potassium silicate spraying caused a significant effect compared to control treatment and the level of $3 \mathrm{mg} \mathrm{L}-1$ was superior in plant length $(110.61 \mathrm{~cm})$, leaf area $(99.7 \mathrm{~cm} 2)$, plant branches number $(8,3)$, plant leaves number (80.02), and plant dry seed yield $(50.7 \mathrm{~g})$. The interactions between the factors caused a significant effect on many studied traits.
\end{abstract}

Keywords Amino acids, Boron, Silicon, Pea

\section{Introduction}

Pea (Pisum sativum L.) is one of the legume plants which is grown for its green and dried seeds, in addition to its importance in improving the soil. Pea growth and yield are influenced by many environmental and nutritional factors. Boron is one of the important nutrients and peas, as legumes, required $\mathrm{B}$ for normal growth processes and nodule development (Mahler and Shafii, 2009, 2004). Boron plays an important role in protecting and moving the IAA, which encourages the increase of cell division and expansion, and then increasing vegetative growth (Barker and Pilbeam, 2006). Amino acids have an important role in many vital processes affecting plant growth and development, as it contributes to reducing the effect of drought and salinity stresses by changing the osmotic potential of plant tissue (Al-Said and Kamal, 2008). It has an important role in metabolic processes by involving in the synthesis of the enzyme and protect plants from the toxicity of ammonia. Amino acids spraying on the vegetative plant parts helps in overcoming the nutrient a deficiency that occurs during growth (Abd El-Aal et al., 2010). Silicon has an important role in plant growth and yield, especially at biotic and abiotic stresses. Silicon may improve the activity of photosynthesis and then increasing the dry matter, which is associated with the efficiency of transport to obtain the best growth and yield (Korndofer and Lepsch, 2001). As well as it caused the reduction of free radical damage and increasing antioxidants enzyme activity (Jasim et al., 2018).

\section{Materials and Methods}

The experiment was carried out during the winter season (2019/2020) in Al-Souera district (50 km southern Baghdad), in silt loam soil (Table 1), to study pea plants response to two levels of boron ( 0 and $2 \mathrm{ml} \mathrm{1-1} \mathrm{liters),} \mathrm{three} \mathrm{levels} \mathrm{of} \mathrm{amino}$ acids $(0,1.5,3.0 \mathrm{ml} \mathrm{L}-1)$ and four levels of potassium silicate $(0,1,2$ and $3 \mathrm{ml} \mathrm{L-1)}$. Randomized complete block design 
(RCBD) with three replications was used. The experimental unit $(4 * 3.2 \mathrm{~m}$ ) included 4 ridges $(4 \mathrm{~m}$ long and $0.8 \mathrm{~m}$ apart). The soil was fertilized by $150 \mathrm{~kg}$ ha- 1 of DAP (18-44-0 NPK) at preparing the soil, and $25 \mathrm{~kg}$ ha-1 urea after two months. Pea seeds were planted on 10/1/2019 in hills $30 \mathrm{~cm}$, and after three weeks it was thinned to one plant per hill. Boron (ethanolamine boron 11\%), amino-acids (Free amino acids:24.8\%), and silicon (a water solution of $35 \%$ $\mathrm{K} 2 \mathrm{O} .4 \mathrm{SiO} 2$ and $12 \% \mathrm{~K} 2 \mathrm{O}$ ) were sprayed twice onto the plant's vegetative pats 45 days after planting (14 November), and 45 days later the first spray (29 December). Plants were harvested in the first half of April 2020. The data were analyzed and the means were compared according to LSD0.05.

\section{Results and discussion}

Table (2) shows that boron spray caused a significant increase in plant length $112.27 \mathrm{~cm}$, compared to control treatment $100.65 \mathrm{~cm}$. This result may be attributed to the positive role of boron in transporting carbohydrates from source to sink and protecting IAA that increases cell division and expansion, which gave the highest opportunity for growth (Barker and Pilbeam, 2006).

Table 1: Some physical and chemical properties of field soil

\begin{tabular}{|c|c|c|c|c|c|c|c|}
\hline Characteristic & $\mathrm{pH}$ & \multirow{2}{*}{$\begin{array}{c}\text { Organic } \\
\text { matter\% }\end{array}$} & \multicolumn{3}{|c|}{ Available } & \multicolumn{2}{|c|}{ Texture } \\
\cline { 3 - 7 } & & & $\mathrm{N}$ & $\mathrm{P}$ & $\mathrm{K}$ & \\
\hline Value & 7.2 & 1.51 & 32 & 16 & 101 & Silt loam & 3.3 \\
\hline
\end{tabular}

Table 2: Effect of boron, amino acids, and Si spraying on plant length $(\mathrm{cm})$

\begin{tabular}{|c|c|c|c|c|c|c|}
\hline \multirow{2}{*}{$\begin{array}{l}\text { Boron } \\
\text { treatment }\end{array}$} & \multirow{2}{*}{$\begin{array}{l}\text { Amino } \\
\text { acids }\end{array}$} & \multicolumn{4}{|c|}{ Potassium Silicate treatments } & \multirow[t]{2}{*}{ boron * amino acids } \\
\hline & & Si 0 & Si 1 & Si 2 & Si 3 & \\
\hline \multirow{3}{*}{ B0 } & A0 & 82.80 & 91.97 & 99.87 & 101.93 & 94.14 \\
\hline & A1 & 100.37 & 103.37 & 112.60 & 103.60 & 105.07 \\
\hline & A2 & 94.83 & 107.13 & 106.87 & 102.13 & 102.74 \\
\hline \multirow{3}{*}{ B1 } & A0 & 108.57 & 111.30 & 104.77 & 105.77 & 107.60 \\
\hline & A1 & 107.93 & 108.80 & 110.73 & 120.13 & 111.90 \\
\hline & $\mathrm{A} 2$ & 106.90 & 107.90 & 124.33 & 130.10 & 117.31 \\
\hline \multicolumn{2}{|c|}{$\mathrm{Si}$ mean } & 100.23 & 105.14 & 109.86 & 110.61 & \\
\hline \multicolumn{2}{|c|}{ LSD0.05 } & \multicolumn{2}{|c|}{$\mathrm{Si}=4.338$} & \multicolumn{2}{|c|}{$\mathrm{T}=10.625$} & N.S \\
\hline \multicolumn{6}{|c|}{ Interaction of boron * potassium silicate } & Boron average \\
\hline \multicolumn{2}{|c|}{ B0 } & 92.67 & 100.94 & 106.44 & 102.56 & 100.65 \\
\hline \multicolumn{2}{|c|}{ B1 } & 107.80 & 109.33 & 113.28 & 118.67 & 112.27 \\
\hline \multicolumn{2}{|c|}{ LSD0.05 } & \multicolumn{4}{|c|}{ N.S } & 3.067 \\
\hline \multicolumn{6}{|c|}{ Interaction of amino acids $*$ potassium silicate } & Amino average \\
\hline \multicolumn{2}{|c|}{ A0 } & 95.68 & 101.63 & 102.32 & 103.85 & 100.87 \\
\hline \multicolumn{2}{|c|}{ A1 } & 104.15 & 106.27 & 111.67 & 111.87 & 108.49 \\
\hline \multicolumn{2}{|c|}{ A2 } & 100.87 & 107.52 & 115.60 & 116.12 & 110.02 \\
\hline \multicolumn{2}{|c|}{ LSD0.05 } & \multicolumn{4}{|c|}{ N.S } & 3.757 \\
\hline
\end{tabular}


It is known that increasing IAA concentration leads to increase internode elongation and consequently the increase of plant length. This is in agreement with Hathili and Al-Jabouri (2016) that pea length was increased significantly at spraying with $50 \mathrm{mg} \mathrm{1-1}$ boron. Amino acids spraying significantly increased plant length, and the level of $3.0 \mathrm{mg} 1-1$ was significantly superior by giving the highest length of 110.02 $\mathrm{cm}$ compared to the control treatment $(100.87 \mathrm{~cm})$. This is consistent with Ghaith and Galal (2014) on pea plants, Zewail (2014), and Salama et al (2019) on the bean. Potassium silicate increasing plant length significantly, and the level of
$3.0 \mathrm{mg} \mathrm{L}-1$ was superior by giving the highest plant length $110.61 \mathrm{~cm}$ compared to the control treatment $(100.23 \mathrm{~cm})$. This is due to silicon works to strengthen the cell walls, which leads to mechanical support of the plant's air parts (Guerriero et al, 2016). This is consistent with Jasim and Hadi (2017)on the broad bean, and Hussein and Muhammad (2017) on eggplant. The interaction between boron, amino acids, and silicon caused a significant effect, and boron $+3.0 \mathrm{mg} \mathrm{1-1}$ amino acids $+3.0 \mathrm{mg} \mathrm{l-1}$ silicon gave the highest plant length $130.10 \mathrm{~cm}$ compared to the control treatment $(82.80 \mathrm{~cm})$.

Table 3. Effect of boron, amino acids, and Si spraying on leaf area

\begin{tabular}{|c|c|c|c|c|c|c|}
\hline \multirow{2}{*}{$\begin{array}{c}\text { Boron } \\
\text { treatment }\end{array}$} & \multirow{2}{*}{$\begin{array}{c}\text { Amino } \\
\text { acids }\end{array}$} & \multicolumn{4}{|c|}{ Potassium Silicate treatments } & \multirow[t]{2}{*}{ boron $*$ amino acids } \\
\hline & & Si 0 & Si 1 & Si 2 & Si 3 & \\
\hline \multirow{3}{*}{ B0 } & A0 & 69.5 & 72.3 & 74.2 & 84.4 & 75.1 \\
\hline & A1 & 78.2 & 81.9 & 87.9 & 95.9 & 86.0 \\
\hline & A2 & 90.8 & 88.7 & 89.3 & 94.2 & 90.8 \\
\hline \multirow{3}{*}{ B1 } & A0 & 85.2 & 88.4 & 92.6 & 99.1 & 91.3 \\
\hline & A1 & 100.4 & 93.0 & 101.8 & 109.1 & 101.1 \\
\hline & A2 & 111.5 & 105.1 & 112.2 & 115.8 & 111.1 \\
\hline \multicolumn{2}{|c|}{ Si mean } & 89.3 & 88.2 & 93.0 & 99.7 & \\
\hline \multicolumn{2}{|c|}{ LSD0.05 } & & 6.80 & $\mathrm{~T}=\mathrm{I}$ & & N.S \\
\hline \multicolumn{6}{|c|}{ Interaction of boron $*$ potassium silicate } & Boron average \\
\hline \multicolumn{2}{|c|}{ B0 } & 79.5 & 80.9 & 83.8 & 91.5 & 83.9 \\
\hline \multicolumn{2}{|c|}{ B1 } & 99.0 & 95.5 & 102.2 & 108.0 & 101.2 \\
\hline \multicolumn{2}{|c|}{ LSD0.05 } & \multicolumn{4}{|c|}{ N.S } & 4.81 \\
\hline \multicolumn{6}{|c|}{ Interaction of amino acids * potassium silicate } & Amino average \\
\hline \multicolumn{2}{|c|}{ A0 } & 77.3 & 80.3 & 83.4 & 91.7 & 83.2 \\
\hline \multicolumn{2}{|c|}{ A1 } & 89.3 & 87.4 & 94.8 & 102.5 & 93.5 \\
\hline \multicolumn{2}{|c|}{ A2 } & 101.2 & 96.9 & 100.8 & 105.0 & 100.9 \\
\hline \multicolumn{2}{|c|}{ LSD0.05 } & \multicolumn{4}{|c|}{ N.S } & 5.89 \\
\hline
\end{tabular}

Table (3) shows that spraying boron caused a significant increase in plant leaf area to $101.2 \mathrm{~cm} 2$ compared to the control treatment $(83.9 \mathrm{~cm} 2)$. Boron contributes to the transfer of most photosynthesis products from leaves to other parts of the plant, which is transmitted through the symplast system. Therefore it affects plant growth, and also has a role in the building cell wall and thus increasing their growth and branch number (Yasin, 2001). This was agreed with AlBayati and Hanashl (2016) on cowpea. Amino acid spraying caused a significant increase in plant leaf area, and the level $1.5 \mathrm{mg} \mathrm{L}-1$ was superior by giving $100.9 \mathrm{~cm} 2$ compared to control treatment ( $83.2 \mathrm{~cm} 2$ ). This is consistent with Abbas and Salman (2018) on cowpea and Zewail (2014) on the bean. Potassium silicate caused a significant increase in plant 
leaf area, and the level $3.0 \mathrm{mg} \mathrm{L}-1$ achieved the highest leaf area $99.7 \mathrm{~cm} 2$ compared to the control treatment that gave $89.3 \mathrm{~cm} 2$. This result was agreed with Rohanipoor et al. (2013) on maize.

Table (4) shows that boron spraying had a significant effect on increasing plant branches number (8.4) compared to the control treatment (7.5). This is consistent with Al-Juhaishi, (2019).

Amino acids spraying caused a significant increase in plant branches number, and the level $3.0 \mathrm{mg} \mathrm{L}-1$ was superior and gave 9.0 branches compared to control treatment which gave 7.1. This is in agreement with Zewail (2014) on bean and Salama et al (2019) on bean plants. Potassium silicate caused a significant increase and $3.0 \mathrm{mg} \mathrm{l-1}$ gave 8.3 branches compared to the control treatment (7.6). This is consistent with Jasim and Hadi (2017 a) on broad bean and Al-Rubaie (2019) on oats. The interaction between boron with amino acids had a significant effect, and boron $+3.0 \mathrm{mg} 1-1$ amino acids gave the highest plant branches number (9.7 branches) compared to the control treatment ( 6.7$)$.

Table 4: Effect of boron, amino acids and Si spraying on number of branches of the plant

\begin{tabular}{|c|c|c|c|c|c|c|}
\hline \multirow{2}{*}{$\begin{array}{c}\text { Boron } \\
\text { treatment }\end{array}$} & \multirow{2}{*}{$\begin{array}{c}\text { Amino } \\
\text { acids }\end{array}$} & \multicolumn{4}{|c|}{ Potassium Silicate treatments } & \multirow[t]{2}{*}{ boron $*$ amino acids } \\
\hline & & Si 0 & Si 1 & Si 2 & Si 3 & \\
\hline \multirow{3}{*}{ B0 } & A0 & 6.5 & 6.8 & 6.7 & 6.7 & 6.7 \\
\hline & A1 & 7.5 & 7.5 & 7.9 & 7.7 & 7.7 \\
\hline & A2 & 7.6 & 7.8 & 8.7 & 9.1 & 8.3 \\
\hline \multirow{3}{*}{ B1 } & A0 & 7.1 & 7.3 & 7.6 & 7.7 & 7.4 \\
\hline & A1 & 7.7 & 8.2 & 8.0 & 8.5 & 8.1 \\
\hline & A2 & 9.1 & 9.5 & 9.8 & 10.3 & 9.7 \\
\hline \multicolumn{2}{|c|}{ Si mean } & 7.6 & 7.9 & 8.1 & 8.3 & \\
\hline \multicolumn{2}{|c|}{ LSD0.05 } & & 0.43 & $\mathrm{~T}=$ & & 0.53 \\
\hline \multicolumn{6}{|c|}{ Interaction of boron $*$ potassium silicate } & Boron average \\
\hline \multicolumn{2}{|c|}{ B0 } & 7.2 & 7.4 & 7.7 & 7.8 & 7.5 \\
\hline \multicolumn{2}{|c|}{ B1 } & 8.0 & 8.3 & 8.5 & 8.8 & 8.4 \\
\hline \multicolumn{2}{|c|}{ LSD0.05 } & \multicolumn{4}{|c|}{ N.S } & 0.30 \\
\hline \multicolumn{6}{|c|}{ Interaction of amino acids * potassium silicate } & Amino average \\
\hline \multicolumn{2}{|c|}{ A0 } & 6.8 & 7.1 & 7.1 & 7.2 & 7.1 \\
\hline \multicolumn{2}{|c|}{ A1 } & 7.6 & 7.8 & 7.9 & 8.1 & 7.9 \\
\hline \multicolumn{2}{|c|}{ A2 } & 8.4 & 8.6 & 9.2 & 9.7 & 9.0 \\
\hline \multicolumn{2}{|c|}{ LSD0.05 } & \multicolumn{4}{|c|}{ N.S } & 0.37 \\
\hline
\end{tabular}

Table (5) shows that boron spraying had a significant effect on increasing plant leaves numbers (88.41), compared to the control treatment (63.20). This is consistent with Al-Bayati and Hanashl (2016) on cowpea. Amino acid spraying caused 
a significant increase in plant leaves numbers, and the level $3.0 \mathrm{mg} \mathrm{1-1}$ was superior by giving 89.20 leaves compared to the control treatment (63.07). This is consistent with Zewail (2014) on bean and Salama et al (2019) on the bean. Potassium silicate caused a significant increase, and the level $3.0 \mathrm{mg} \mathrm{L}-1$ achieved 80.02 leaves compared to the control treatment (70.12 leaves).
This is consistent with Jasim and Hadi (2017 a) on broad bean and Hussein and Muhammad (2017) on eggplant. The interaction of boron and amino acids caused a significant effect, and boron+ $3.0 \mathrm{mg} \mathrm{1-1}$ amino acid was superior by giving 104.53 leaves compared to the control treatment that gave 50.07 leaves. The interaction of amino acids and potassium silicates caused a significant effect, and the treatment of 3.0 amino acids +3.0 potassium silicates gave 96.93 leaves compared to the control treatment (57.50).

Table 5: Effect of boron, amino acids and Si spraying on plant leaves number

\begin{tabular}{|c|c|c|c|c|c|c|}
\hline \multirow[t]{2}{*}{ Boron treatment } & \multirow{2}{*}{$\begin{array}{l}\text { Amino } \\
\text { acids }\end{array}$} & \multicolumn{4}{|c|}{ Potassium Silicate treatments } & \multirow[t]{2}{*}{ boron $*$ amino acids } \\
\hline & & Si 0 & Si 1 & Si 2 & Si 3 & \\
\hline \multirow{3}{*}{ B0 } & A0 & 45.80 & 46.80 & 51.57 & 56.10 & 50.07 \\
\hline & A1 & 59.07 & 66.30 & 68.23 & 69.03 & 65.66 \\
\hline & A2 & 64.47 & 72.70 & 77.60 & 80.73 & 73.87 \\
\hline \multirow{3}{*}{ B1 } & A0 & 69.20 & 77.67 & 77.17 & 80.30 & 76.08 \\
\hline & A1 & 88.77 & 83.70 & 85.13 & 80.80 & 84.60 \\
\hline & $\mathrm{A} 2$ & 93.40 & 103.13 & 108.47 & 113.13 & 104.53 \\
\hline \multicolumn{2}{|c|}{ Si mean } & 70.12 & 75.05 & 78.03 & 80.02 & \\
\hline \multicolumn{2}{|c|}{ LSD0.05 } & \multicolumn{4}{|c|}{$\mathrm{Si}=3.813$} & 4.670 \\
\hline \multicolumn{6}{|c|}{ Interaction of boron $*$ potassium silicate } & Boron average \\
\hline \multicolumn{2}{|l|}{ B0 } & 56.44 & 61.93 & 65.80 & 68.62 & 63.20 \\
\hline \multicolumn{2}{|l|}{ B1 } & 83.79 & 88.17 & 90.26 & 91.41 & 88.41 \\
\hline \multicolumn{2}{|c|}{ LSD0.05 } & \multicolumn{4}{|c|}{ N.S } & 2.696 \\
\hline \multicolumn{6}{|c|}{ Interaction of amino acids $*$ potassium silicate } & Amino average \\
\hline \multicolumn{2}{|l|}{ A0 } & 57.50 & 62.23 & 64.37 & 68.20 & 63.07 \\
\hline \multicolumn{2}{|l|}{ A1 } & 73.92 & 75.00 & 76.68 & 74.92 & 75.13 \\
\hline \multicolumn{2}{|l|}{ A2 } & 78.93 & 87.92 & 93.03 & 96.93 & 89.20 \\
\hline \multicolumn{2}{|c|}{ LSD0.05 } & \multicolumn{4}{|c|}{6.605} & 3.303 \\
\hline
\end{tabular}

Table (6) shows that boron spray caused a significant increase in chlorophyll index to 43.91(SPAD), compared to the control treatment 41.12 (SPAD). This is consistent with Al-Qazzaz (2014) on chickpea. Amino acid spraying 
increasing chlorophyll index significantly, and the level 3.0 mg 1-1 was superior and gave 44.09(SPAD) compared to a control treatment (40.84 SPAD). This is consistent with AlQazzaz (2014) on chickpea. The triple interaction between boron, amino acids, and silicon caused a significant effect,

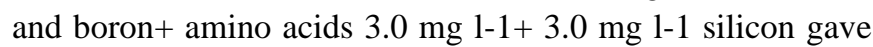
the highest rate of 43.86 (SPAD) compared to the control treatment which gave 35.83(SPAD).

Table 6: Effect of boron, amino acids and Si spraying on chlorophyll index (SPAD)

\begin{tabular}{|c|c|c|c|c|c|c|}
\hline \multirow{2}{*}{$\begin{array}{l}\text { Boron } \\
\text { treatment }\end{array}$} & \multirow{2}{*}{$\begin{array}{l}\text { Amino } \\
\text { acids }\end{array}$} & \multicolumn{4}{|c|}{ Potassium Silicate treatments } & \multirow[t]{2}{*}{ boron $*$ amino acid } \\
\hline & & Si 0 & Si 1 & Si 2 & Si 3 & \\
\hline \multirow{3}{*}{ B0 } & A0 & 35.83 & 39.97 & 40.23 & 41.57 & 39.40 \\
\hline & A1 & 41.33 & 41.93 & 40.60 & 42.07 & 41.48 \\
\hline & A2 & 43.83 & 41.77 & 40.43 & 43.87 & 42.47 \\
\hline \multirow{3}{*}{ B1 } & A0 & 41.10 & 39.87 & 44.33 & 43.83 & 42.28 \\
\hline & A1 & 46.40 & 42.93 & 41.33 & 44.33 & 43.75 \\
\hline & A2 & 42.33 & 46.77 & 46.23 & 47.47 & 45.70 \\
\hline \multicolumn{2}{|c|}{ Si mean } & 41.81 & 42.21 & 42.19 & 43.86 & \\
\hline \multicolumn{2}{|c|}{ LSD0.05 } & \multicolumn{2}{|c|}{$\mathrm{Si}=\mathrm{N} . \mathrm{S}$} & \multicolumn{2}{|c|}{$\mathrm{T}=4.106$} & N.S \\
\hline \multicolumn{6}{|c|}{ Interaction of boron $*$ potassium silicate } & Boron average \\
\hline \multicolumn{2}{|c|}{ B0 } & 40.33 & 41.22 & 40.42 & 42.50 & 41.12 \\
\hline \multicolumn{2}{|c|}{ B1 } & 43.28 & 43.19 & 43.97 & 45.21 & 43.91 \\
\hline \multicolumn{2}{|c|}{ LSD0.05 } & \multicolumn{4}{|c|}{ N.S } & 1.185 \\
\hline \multicolumn{6}{|c|}{ Interaction of amino acids * potassium silicate } & Amino average \\
\hline \multicolumn{2}{|c|}{ A0 } & 38.47 & 39.92 & 42.28 & 42.70 & 40.84 \\
\hline \multicolumn{2}{|c|}{ A1 } & 43.87 & 42.43 & 40.97 & 43.20 & 42.62 \\
\hline \multicolumn{2}{|c|}{ A2 } & 43.08 & 44.27 & 43.33 & 45.67 & 44.09 \\
\hline \multicolumn{2}{|c|}{ LSD0.05 } & \multicolumn{4}{|c|}{ N.S } & 1.452 \\
\hline
\end{tabular}

Table (7) shows that boron spraying had a significant effect on increasing plant green pods yield $(57.7 \mathrm{~g})$, compared to the control treatment $(39.8 \mathrm{~g})$. This is consistent with Jasim and Al-Dulaime (2014) on broad bean and Al-Bayati and Hanashl (2016) on cowpea. Amino acids spraying caused a significant increase in plant green pods yield, and the level $3.0 \mathrm{mg} \mathrm{l-1}$ was superior by giving $57.9 \mathrm{~g}$ compared to control treatment ( $39.5 \mathrm{~g}$ ). This is consistent with Salama et al (2019) and Zewail (2014) on the bean. Potassium silicate caused a significant increase, and the level $2.0 \mathrm{mg} \mathrm{L}-1$ achieved
$51.1 \mathrm{~g}$ compared to the control treatment $(45.0 \mathrm{~g})$. This is consistent with Jasim and Hadi (2017 b) on the broad bean. The interaction of boron and amino acids caused a significant effect, and boron+ $3.0 \mathrm{mg} \mathrm{L}-1$ amino acid was superior by giving $71.8 \mathrm{~g}$ compared to the control treatment that gave $28.3 \mathrm{~g}$. The interaction of boron and amino acids caused a significant effect, and the treatment of boron+ $3.0 \mathrm{mg} \mathrm{L}-1$ amino acids gave $69.2 \mathrm{~g}$ compared to control treatment $(31.5 \mathrm{~g})$. 
Science Archives (2021) Vol. 2 (1), 1-8

Table 7: Effect of boron, amino acids and Si spraying on plant dry seed yield (g)

\begin{tabular}{|c|c|c|c|c|c|c|}
\hline \multirow{2}{*}{$\begin{array}{l}\text { Boron } \\
\text { treatment }\end{array}$} & \multirow{2}{*}{$\begin{array}{l}\text { Amino } \\
\text { acids }\end{array}$} & \multicolumn{4}{|c|}{ Potassium Silicate treatments } & \multirow[t]{2}{*}{ boron $*$ amino acids } \\
\hline & & Si 0 & Si 1 & Si 2 & Si 3 & \\
\hline \multirow{3}{*}{ B0 } & A0 & 28.3 & 29.7 & 33.6 & 34.5 & 31.5 \\
\hline & A1 & 36.9 & 42.7 & 38.1 & 46.5 & 41.1 \\
\hline & A2 & 42.2 & 47.4 & 49.8 & 48.0 & 46.9 \\
\hline \multirow{3}{*}{ B1 } & A0 & 44.7 & 47.0 & 48.7 & 50.1 & 47.6 \\
\hline & A1 & 51.2 & 52.7 & 64.8 & 56.9 & 56.4 \\
\hline & A2 & 66.5 & 69.2 & 71.8 & 68.1 & 69.2 \\
\hline \multicolumn{2}{|c|}{ Si mean } & 45.0 & 48.1 & 51.1 & 50.7 & \\
\hline \multicolumn{2}{|c|}{ LSD0.05 } & \multicolumn{4}{|c|}{$\mathrm{Si}=2.7$} & 3.3 \\
\hline \multicolumn{6}{|c|}{ Interaction of boron $*$ potassium silicate } & Boron average \\
\hline \multicolumn{2}{|c|}{ B0 } & 35.8 & 39.9 & 40.5 & 43.0 & 39.8 \\
\hline \multicolumn{2}{|c|}{ B 1} & 54.1 & 56.3 & 61.8 & 58.4 & 57.7 \\
\hline \multicolumn{2}{|c|}{ LSD0.05 } & \multicolumn{4}{|c|}{ N.S } & 1.0 \\
\hline \multicolumn{6}{|c|}{ Interaction of amino acids $*$ potassium silicate } & Amino average \\
\hline \multicolumn{2}{|c|}{ A0 } & 36.5 & 38.4 & 41.2 & 42.8 & 39.5 \\
\hline \multicolumn{2}{|c|}{ A1 } & 44.5 & 47.7 & 51.5 & 51.7 & 48.9 \\
\hline \multicolumn{2}{|c|}{$\mathrm{A} 2$} & 54.4 & 58.3 & 60.8 & 58.1 & 57.9 \\
\hline \multicolumn{2}{|l|}{ LSD0.05 } & \multicolumn{4}{|l|}{ N.S } & 2.3 \\
\hline
\end{tabular}

\section{Conflict of Interest}

The author hereby declares no conflict of interest.

\section{Consent for publication}

The author declares that the work has consent for publication.

\section{Funding support}

The author declares that they have no funding support for this study.

\section{References}

Abbas, K.B. \& Salman, F.A. (2018). The effect of the addition of boron and amino acids on some characteristics of vegetative growth and the occurrence of cowpea (Vigna unguiculata L.) . Journal of the University of Karbala scientific. 16 (4), 99-88.
Abd El-Aal, F.S., Shaheen, A.M., Ahmed, A.A. Mahmoud, A.R. (2010). Effect of foliar application of urea and amino acids mixtures as antioxidants on growth, yield and characteristics of squash. Res. J. Agric. and Biol. Sci., 6(5), 583-588.

Al-Bayati, S.S.M. \& Hanashl, M.A. (2016). Cowpea response to sprinkling with boron and carbolizer in the growth and yield of green pods. Iraqi Agric. Sci. J., 47 (3), 708-715.

Al-Juhaishi, W.K.S. (2019). The effect of phosphate fertilization and boron spray on some growth characteristics and local livestock yield (Vigna radiata L.) in alluvial mixture soil. Kirkuk University Journal of Agricultural Science, 10 (1), 104-110.

Al-Qazzaz, A.G.M. (2014). The role of foliar nutrition with zinc and boron in some growth indicators for chickpea. Ibn al-Haytham J. Pure and Appl. Sci., 27 (2), 13-23.

Al-Rubaie, S.H.A. (2019). Response of two varieties of oats to spray ascorbic acid, wire, and potassium silicate. PhD thesis. faculty of Agriculture. Albasrah University, Iraq.

Al-Said, M.A. \& Kamal, A.M. (2008). Effect of foliar spray with folic acid and some amino acids on flowering yield and quality of sweet pepper. $J$. Agric. Sci. Mansoura Univ., 33(10), 7403 - 7412.

Barker, A.V. \& Pilbeam D. J. (2006). Handbook of Plant Nutrition, CRC Press New York. 


\section{Science Archives (2021) Vol. 2 (1), 1-8}

Ghaith, R.H. \& Galal, R.M. (2014). Response of pea plant (Pisum sativum L.) Growth and yield for spraying of amino acid and boron. Egypt. J. Appl. Sci., 29 (3), 154-173.

Guerriero, G.; Hausman, J., Legay, S. (2016). Silicon and the Plant Extracellular Matrix. Front Plant Sci., 7, 463.

Hathili, K.H. \& Al-Jubouri, F.F. (2016). Effect of molybdenum and boron on some growth characteristics of beans (Vicia faba L.). Basra J. Agric. Sci., 29 (1), 201-213.

Hussein, W.A. \& Mohamed, M.M. (2017). White eggplant plants response to boron spray and potassium silicate. Assiut J. Agric. Sci., 48 (1-1), 394-401.

Jasim, A.H. \& Hadi, K.F. (2017 a). Effect of silicon, GA3 and humic acid on broad bean plant growth. Euphrates J. Agric. Sci., 9(4), 86-96.

Jasim, A.H. \& Hadi, K.F. (2017b). Effect of silicon, GA3 and humic acid on green pods yield of broad bean. Euphrates J. Agric. Sci., 9(4), 117130.

Jasim, A.H. \& Al-Dulaimi, K.L. (2014) Effect of adding organic fertilizers and foliar application of humic acid and seaweed extract in growth and green pod yield of broad bean ( Vicia faba L. ). Euphrates J.Agric. Sci., 7(1), 163-172.

This work is licensed under a Creative Commons Attribution 4.0 International License.

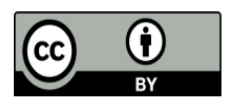

Jasim, A.H., Merhij, E.I., Atab, H.A., Abdalwahed, S.H. (2018) Effect of Chemical and Organic Fertilizers and Interactions With High Potash and Silicon Spraying on Vicia faba L. Antioxidants in Salinity Soil. Indian Journal of Ecology, 45(4), 802-805.

Korndorfer, G. \& Lepsch, I. (2001). Effect of silicon on plant growth and crop yield. Studies in Plant Science, 8, 133-147.

Mahler, R.L. \& Shafii, B. (2009). Relationship between Soil Test Boron and Pea Yields in the Inland Pacific Northwest. Communications in Soil Science and Plant Analysis, 40(15-16), 2603-2615.

Rohanipoor, A., Norouzi, M., Moezzi, A., Hassibi, P. (2013). Effect of silicon on some physiological properties of maize (Zea mays L.) under salt stress. J. Biol. Environ. Sci., 7(20), 71-79.

Salama, A.M., Azoz, S.N.. El-Taher, A.M. (2019). Influence of foliar spray by algae extract and amino acid on botanical characters and seed chemical composition of common bean plant (Phaseolus vulgaris L.). Int. J. Adv. Res., 7(4), 264-271

Zewail, R.M.Y. (2014) Effect of seaweed extract and amino acids on growth and productivity and some bio-constituents of common bean (Phaseolus vulgaris L) plants. J. Plant Production, Mansoura Univ., $5(8), 1441-1453$.

\section{How to cite this article:}

Jasim, A.H. and Mohsen, M.H. (2021). Response of pea to boron, amino acids, and silicon spray. Science Archives, Vol. 2 (1), 1-8. http://dx.doi.org/10.47587/SA.2021.2101 